\title{
The Level of Multiple Intelligences in Arabic Language Textbooks for Grades from $(1-4)$ in Jordan in Light of Gardner's Theory
}

\author{
Saleh Mohammad Abu Jado \\ Faculty of Educational Sciences and Arts/UNRWA, Amman, Jordan \\ Email: s.abujado@unrwa.org
}

Received 18 June 2015; accepted 9 August 2015; published 12 August 2015

Copyright (C) 2015 by author and Scientific Research Publishing Inc. This work is licensed under the Creative Commons Attribution International License (CC BY). http://creativecommons.org/licenses/by/4.0/

(c) (i) Open Access

\section{Abstract}

This study aims to investigate the level of inclusion and balance of multiple intelligences in the Arabic Language textbooks in light of Gardner's Theory using the analytical descriptive approach. Eight textbooks in grades (1 - 4) for the first and second semesters were taught in schools in the Jordanian educational system in 2013/2014. The selected textbooks were analyzed using Multiple Intelligences (MI) checklist devised by the researcher based on the framework of the Theory of Multiple Intelligences to examine them in relation to different intelligences as reflected through various activities, questions and tasks. The study sample consisted of all Arabic Language textbooks for the grades from 1 - 4. Results of the study showed that the verbal/linguistic intelligence in the textbooks in general scored the highest frequency amongst all types of intelligence; meanwhile the musical intelligence in the textbooks scored the lowest frequency among all types of intelligence. The study concluded with a recommendation to consider the necessity of employing all types of intelligence in designing Arabic language textbooks for young learners.

\section{Keywords}

Gardner, Multiple Intelligences, Arabic Language, Textbooks, Jordan

\section{Introduction}

Multiple Intelligences theory and its applications in the educational settings are growing so quickly. Many educators begin to adopt MI based instruction as a way to overcome the challenges they encounter with their stu- 
dents as a result of their individual differences and their learning styles. These challenges may be represented in their inability to reach most of their students. As a result, they become frustrated and their students lose interest in the teaching learning process in general. These difficulties may be caused by the uniform way in which they address their students. There are currently thousands of teachers and ten thousands of learners undergoing MI based classroom instruction all over the world (Campbell, 2000).

Using MI in textbooks and instruction means that students learn and show their understanding in many different ways (Hoerr, 2000). Multiple Intelligences theory represents a model of instruction that has no distinct rules other than the requirements imposed by the cognitive components of the intelligences themselves. Teachers can pick up and choose from many activities, implementing the theory in a way appropriate to their own unique teaching style and cope with their educational philosophy (Armstrong, 1994). Studies on the Multiple Intelligences theory gained momentum based on the works of Gardner (1983). This theory is a learner-based philosophy that has far reaching implications in education in general and in language teaching in particular (Tahriri \& Disvar, 2011). Due to the emergence of MI theory, changes have been made in school curricula in order to consider the new view of human capacities. Many public and private schools started to base their curricula upon multiple intelligences theory after the publication of Gardner's Frames of mind in 1983 (Weiner, 2001).

Successful and experienced teachers do not deal with some concept or some content area in a uniform way, rather they diversify their instruction methods in such a way that the same content area or concept is dealt with in many different ways. This will result in the involvement of more of the students' multiple intelligences at the same time, and thus, involving more students in the teaching-learning process. In multiple intelligences terms, this variety provides multiple tracks to understanding necessary to engage the multiple intelligences that students bring to the classroom (White, Blythe, \& Gardner, 1995).

To develop instruction under the MI philosophy, the teacher has to translate the linguistic materials into activities that cope with MI Theory. The best way to approach curriculum and textbook development using the theory of multiple intelligences is by thinking about how we can translate into the languages of other intelligences, namely those proposed by Gardner in his MI theory (Armstrong, 1994).

As teachers and educators, we should consider student differences and acknowledge a variety in excellence. Gardner's theory provides a powerful framework in helping educators create authentic and innovative learning experiences. It provides a scope to validate and build on the strengths of each individual student. Although MI is not a step-by-step recipe for success in education, it provides a powerful and pragmatic structure for designing curriculum. Furthermore, MI enables educators to address the needs of each student on an individual basis and makes content and curriculum exciting and accessible to every learner. As our students continue to change and diversify, we must persevere and continue to find new ways to support and engage a variety of learners (Johnson, 2007).

\section{Theoretical Background}

There have been two main theories which appeared in the $20^{\text {th }}$ century and which were an attempt to interpret human differences and to design educational models around these differences: Learning Styles Theory which has its roots in the psychoanalytical community and Multiple Intelligences Theory which is the fruit of cognitive science (Silver, Strong \& Perrini, 1997: p. 22). Multiple intelligences theory was first proposed by Howard Gardner, a professor of cognition and education at Harvard University. He considered it "as a pluralistic view of mind which recognizes many different and discrete facets of cognition and acknowledges that people have different cognitive strengths and contrasting cognitive styles. Since then, educators have become very interested to apply this theory as a means through which they can improve teaching and learning in a multiplicity of ways. The theory represents a new approach towards the nature of intelligences (Goodenough, 2000).

The MI theory as developed by Gardner is based on the understanding that people learn utilizing different types of intelligences (Griggs et al., 2009). This entails that individual learning varies across a platform of human potentialities in which individual differences stemming from bio-psychological and cultural factors affect their skills sets and even abilities. Multiple intelligences among intelligence theories specifically caters to the diversity characterizing individuals, and hence leads to a more effective and reasonable approach to address different learners in the classroom. The implications for educators and students are tremendous in terms of the richness and flexibility MI brings to teaching and learning.

As educators develop and utilize pedagogies that consciously attempt to engage students in a variety of ways, knowing which intelligences students possess is critical to effective instruction. The benefit of this evaluation is 
two-fold. If instructors know the strengths of their students, they can better prepare engaging and relevant lessons that correlate with those strengths. Secondly, students, knowing their strengths, can engage various strategies to enhance their learning accordingly (Griggs et al, 2009).

Gardner confirms that intelligence is more than a single property of human mind and someone who is not strong in mathematical ability should not be considered as "not intelligent", because that same person could be intelligent in another area. In other words, while all students are not verbally or mathematically gifted, they may have an expertise in other areas, such as music, spatial relations, or interpersonal knowledge (Botelho, 2003). Gardner sought to broaden the scope of human potential beyond the limitations of the IQ scores. Instead, Gardner suggested that intelligence has more to do with the capacity of solving problems and fashioning products in a context rich and naturalistic setting (Armstrong, 2009).

Gardner (1983) believes that intelligence cannot be measured by traditional IQ tests and his view of intelligence differs from traditional ones in that each individual has potential intelligence in different areas. As he explains how brain works, he gives us the rationale behind his theory: It is fundamentally misleading to think about a single intelligence, a single mind, and a single problem-solving capacity. And so, along with many others, he tried to make the argument that the brain consists of many "modules," "organs," "intelligences," each of which operates according to its own rules in relative autonomy from the others.

Gardner encourages a shift from the more traditional understanding of intelligence to a more holistic perspective that enhances and validates each and every part of a person's mind, and he suggests that people possess eight different intelligences: linguistic intelligence, musical intelligence, logical-mathematical intelligence, spatial intelligence, bodily-kinesthetic intelligence, interpersonal intelligence, intrapersonal intelligence, and naturalist intelligence (Johnson, 2007).

The natural application of MI to the field of education has fully revolutionized learning in many schools. It transfers the focus from the more traditional emphasis on linguistic and mathematical intelligences, and encourages teachers and students to enhance and develop each of the eight intelligences (Gardner, 1999).

Gardner (1983) states that MI theory is an amazing approach toward learning and concluded that the traditional notion of intelligence as measured by IQ testing is too limited and there are not just two ways to be intelligent, but many ways. Ehrman (2003) explained that people—in accordance with Gardner's theory-vary according to their different aspects of their intelligence, so it would be better to know that one of the influential factors in learning is personal differences. One issue which makes people different from each other is related to their intelligence preferences. Gardner provided a means of mapping the broad range of abilities that human possess by grouping their capabilities into the following eight comprehensive categories or intelligences (Armstrong, 2009; Gardner, 1983):

1) Verbal/Linguistic: The capacity to use words effectively, whether orally or in writing. This intelligence includes the ability to think in words and to use language to express complex meanings and to understand the meaning and order of words to reflect on our use of language. This intelligence is the most widely shared human competence and is evident in novelists, poets, journalists, and public speakers. Some users include rhetoric, mnemonics, explanation and meta-language.

2) Logical-Mathematical: The ability to calculate, quantify, consider propositions and hypotheses, and carry out complete mathematical operations effectively. It enables us to perceive connections and relationships and to use abstract, symbolic thought; reasoning skills; and inductive and deductive thinking patterns. This intelligence includes sensitivity to logical patterns and relationships, statements and propositions, functions, and other related abstractions. This kind of processes used in the service of logical-mathematical intelligence includes categorization, classification, calculation, and hypothesis testing.

3) Spatial-Visual: The ability to perceive the visual-spatial world accurately and to perform transformations upon those perceptions. This intelligence includes sensitivity to color, line, shape, form, space, and the relationships that exist between these elements. It includes the capacity to visualize, to graphically represent visual or spatial ideas, and to orient oneself appropriately in spatial matrix. People with a high spatial and visual intelligence perceive the visual world more accurately to perform modifications and transformations in accordance with one's initial perceptions, and to be able to re-produce aspects of one's perceptions, even in the absence of relevant physical stimuli.

4) Bodily-kinesthetic: Expertise in using one's whole body to express ideas and feelings and facility in using one's hands to produce or transform things. This intelligence includes specific physical skills such as coordination, balance, strength, flexibility, and speed, as well as proprioceptive, tactile, and haptic capacities. People who 
possess bodily intelligence are able to do complex and delicate movements. They are successful in using their body to express feelings and using their hands to produce things.

5) Musical: The ability to perceive, discriminate, transform, and express musical forms. This intelligence includes sensitivity to the rhythm, pitch or melody, and timbre or tone color of a musical piece. People with this type of intelligence are usually singing or drumming to themselves. They are quite aware of sounds others may miss.

6) Interpersonal: The ability to perceive and make distinctions in the moods, intentions, motivations, and feelings of other people. This can include sensitivity to facial expressions, voice, and gestures; the capacity for discriminating among different types of interpersonal cues; and the ability to respond effectively to those cues in some pragmatic way.

7) Intrapersonal: The ability to understand oneself and one's thoughts and feelings and to use this knowledge to act adaptively on the basis of that knowledge. This intelligence includes having an accurate picture of oneself; motivations, temperaments, awareness of inner moods, intentions, and desires; and the capacity for selfunderstanding, self-discipline, and self-esteem. This intelligence includes not only self-appreciation but the human condition as well.

8) Naturalist: The ability to distinguish patterns in nature. It involves the recognition of the classification of numerous species of individual's environment. This also includes sensitivity to other natural phenomena and, in the case of those growing up in an urban environment, the capacity to discriminate among inanimate objects such as cars, sneakers and CD covers.

The various intelligence types represent a pluralistic panorama of learner's individual differences; they are understood as personal tools each individual possesses to make sense out of new information and to store it in such a way that it can be easily retrieved when needed for use (Arnold \& Fonseca, 2004: p. 120). The eight areas reflect the range of intelligent human functioning. While each area is identified as a discrete intelligence, each also interacts with others in complex ways to produce the richness of human behavior and achievement. Ordinary human functioning requires such interaction. Many people will exhibit a highly-developed intelligence, not perhaps in their occupation, but in interests, hobbies, in personal projects, or in personal and social relationships (Hyland, 2011: p. 6).

Stefanakis (2002) believes that applying MI in teaching settings is an excellent way to accommodate diversity in the classroom, as well as to empower students to succeed in learning. In the words of Stefanakis: all children have multiple intelligences and it is the job of educators to use their capabilities, not disabilities, to become more effective teachers.

Since this study aims to investigate the level of MI in the textbooks used in teaching Arabic language in order to know how the contents of the textbooks can help language learners enhance their intelligences, there is a need to address the role of textbooks in language teaching (Botelho, 2003). Many researchers have emphasized the significance and the use of textbooks in language teaching (Palmberg, 2001). However, researchers have also indicated that teachers tend to use textbooks heavily (Sheldon, 1988) and that sometimes they use the textbooks from cover to cover. Researchers state that, due to the important role of textbooks in language teaching, teachers must be well prepared to use text books carefully and more efficiently in order to take into account learners' differences, styles and needs (Botelho, 2003).

Some researchers try to explain why textbooks have been major tools in language teaching and attempt to determine the elements that contribute to the use of textbooks in most language classrooms throughout the world. Sheldon (1988) identified the following reasons that contribute to the constant use of textbooks: a) It is hard for teachers to develop their own teaching materials; b) Teachers do not have much time to create new materials and c) Textbooks reduce preparation time because they provide activities that are ready to use. Richards (2001) added that textbooks provide effective language models and input, and they can train teachers. But, he mentioned some negative aspects related to non-authentic materials, content distortion, and expensive prices. He also mentioned that they can limit teachers' potential if they follow books strictly.

Finally, the literature on intelligence shows that many psychologists have attempted to define and measure human intellectual capabilities. One of these psychologists was Galton who believed that intelligence was inherited (Gardner, 1999: p. 2), and he believed that he could measure intelligence, so he developed formal IQ tests in the late nineteenth century. In 1906 Alfred Binet devised the most well-known IQ test in the world. The IQ test was modified to best suit American society in the 1920s and 1930s (Gardner, 1999: p. 12) and became known as the Stanford-Binet IQ test. Many psychologists claim that IQ tests are valid for predicting academic 
achievement, as they were primarily created; however, they cannot predict success in life outside school and they cannot determine what intelligence is or how intelligent a person is (Botelho, 2003). Gardner (1999) challenged this commonly held belief, suggesting that our culture had defined intelligence too narrowly. Snider (2001) mentions that, "before Gardner, intelligence was thought to be a static, single construct” (p. 5).

\section{Research Problem and Questions}

The problem of the current study stems from the basic principle of education that stresses the importance of considering individual differences among students in designing teaching methods and materials to meet their different learning styles. It stems as well from the recommendations of the $4^{\text {th }}$ International Educational Conference on the New Educational Trends and its applications held in Amman in 2012 and which confirmed the importance of designing the curricula of school subjects in light of the intelligence theories in general and Multiple Intelligences theory in particular. Furthermore, the problem of this article comes from the fact that Arabic language textbooks for the first four grades should be developed and redesigned to contribute positively to improving the reading and writing skills of students who suffer serious difficulties in mastering these crucial skills as recommended by the Ministry of Education in Jordan. It is believed that incorporating Multiple Intelligences in school textbooks especially in language teaching would have considerable impact on students' learning and acquisition of its basic skills.

It's obvious that the Arabic language textbooks for the first four grades in Jordan represent the foundation for the rest of the school subjects not only in the primary stage but in all school stages as well. The importance of analyzing Arabic language textbooks also represents a diagnostic and remedial process that leads to improving and developing the curricula and textbooks. Therefore, all countries around the world tend to revise curricula and textbooks in all school subjects periodically or as needed to overcome any shortcomings that might arise during the cycle of implementation, or as a result of continuous development in different aspects of human communities.

Finally, the research problem stems from the fact that Arabic Language textbooks of the first four grades in Jordan - to the best of the author's knowledge- have not been analyzed in the light of the Multiple Intelligences theory to investigate the level of inclusion of the eight intelligences proposed by Gardner in these textbooks. In particular, this study seeks to answer the following questions:

1) Question 1: What is the level of existence and goodness of fit of the Multiple Intelligences in Arabic language textbooks of $1^{\text {st }}$ Grade?

2) Question 2: What is the level of existence and goodness of fit of the Multiple Intelligences in Arabic language textbooks of $2^{\text {nd }}$ Grade?

3) Question 3: What is the level of existence and goodness of fit of the Multiple Intelligences in Arabic language textbooks of ${ }^{\text {3rd }}$ Grade?

4) Question 4: What is the level of existence and goodness of fit of the Multiple Intelligences in Arabic language textbooks of $4^{\text {th }}$ Grade?

5) Question 5: What is the level of existence and goodness of fit of the Multiple Intelligences in Arabic Language textbooks as a whole?

\section{Purpose of the Study}

The purpose of this study is to investigate how Arabic language textbooks of the first four grades in Jordan respond to MI theory and to what extent they include the intelligences in the contents provided. Before embarking on this research project, the researcher observed that not all of the intelligences are included in the current textbooks and that there is a need to supplement the intelligences not included in Arabic language textbooks to best enhance all the intelligences and benefit all types of learners teachers deal with in Arabic language classes.

\section{Significance of the Study}

This study examines the level of inclusion of the theory of Multiple Intelligences (MI) in the Arabic Language textbooks of the first four grades in Jordan. Multiple Intelligences approach is considered by a wide range of educational scholars as an effective platform for $21^{\text {st }}$ century educational and instructional methodologies based on the understanding of the value of diversity in today’s classrooms (McFarlane, 2011). In this context, Multiple 
Intelligences theory suggested that each individual has different aptitudes and abilities in several areas and that each person has multiple types of intelligence that are combined together differently (Botelho, 2003).

The findings of the current study may benefit the authors of Arabic Language textbooks in all grades not only in the first four grades in the country, through providing them with appropriate guidelines and suggestions to build the school textbooks based on the Multiple Intelligences theory. They may also contribute in empowering the target group of this study, who undergo through a very fundamental stage which lays down the foundations of their entire school life not only in Language learning but in all other subjects as well, because Arabic is the language of instruction in all the other school subjects. This stage represents a very critical and crucial period for students of (6 - 10 years), who are in need to study curricula and textbooks that develop and meet their different intelligences.

The significance of the current study also stems from the fact that it might be the first study which has attempted to investigate the level of MIs in the Arabic Language textbooks for the first four grades in Jordan.

\section{Limitations of the Study}

This study has three major limitations. First, it focuses on Arabic Language textbooks for the grades from 1 - 4 in Jordan in both public and private schools in the scholastic year 2013/2014; therefore the results may not apply to textbooks of other subjects or other scholastic years. Second, categorizing all contents of the relevant textbooks as representatives of intelligence types fully relies on the tool prepared and verified for this purpose by the researcher (Annex A), therefore using another tool may lead to different results. Third, the number of the textbooks studied is limited to eight (two for each grade) which makes generalizing the findings rather more difficult. Despite these limitations, this study can be considered as an important attempt to put the profile of Arabic language textbooks in Jordan for the first four grades in terms of their relationship with MI theory.

\section{Definition of Terms}

The following definitions are adopted for this study:

1) Textbook: Integrated skills general Arabic language book used for teaching students in public and private schools in Jordan.

2) Multiple Intelligences: A bio psychological potential to process information that can be activated in a cultural setting to solve problems or create products that are of value in a culture (Gardner, 1999: pp. 33-34).

\section{Literature Review}

Reviewing the literature of Multiple Intelligences theory shows abundance of research studies addressing a wide range of issues related to this theory. For the purposes of this study, the researcher will present some studies that tackled variables in teaching and learning using MI theory or analyzing textbooks to investigate the level of MIs embedded in their different types of contents.

Palmberg (2001) conducted a research study on a group of student-teachers to evaluate how current Foreign Language (FL) texts are related to MI theory and to what extent they engage MI in FL teaching. The study showed that not all of the nine intelligence types were included in the activities of the textbooks, and some of the intelligences predominate in the text books such as the verbal-linguistic and intrapersonal intelligences.

In the same line, Botelho (2003) reviewed six textbooks to examine the dominant intelligences in their activities. The results of the analysis indicated that verbal/linguistic, intrapersonal, spatial/visual and interpersonal are the main intelligences in the targeted books. The results of the analysis in this study showed that ver$\mathrm{bal} /$ linguistic and intrapersonal are observed in $100 \%$ of the activities; spatial/visual was observed in $90.08 \%$; and interpersonal observed in $76.07 \%$ of all the activities in the targeted books. The less observed intelligences are logical/mathematical, bodily/kinesthetic, musical, and naturalist.

Furthermore, Kelly (2005) developed an original framework for using MIs to model learning characteristics. He tried to find a relationship between MIs and learning styles and strategies. He found that the concept of intelligences and styles as predictive of language performance was supported by evidence. Indeed, results showed the positive effectiveness of different MI-based styles in students' learning process.

Moreover, Al-Tawalbeh (2007) carried out another research study to investigate the level of MIs in the History textbook for the $10^{\text {th }}$ graders in Jordan schools. The results showed that all intelligences were included in 
the textbook by different rates. The study concluded that intrapersonal intelligence has dominated all other intelligences, while musical intelligence ranked the least without any frequency.

Another study was conducted by Hou (2010) to examine the role of MIs theory in foreign language behavior and performance. Participants of the study were 2545 Taiwanese college students who were given an English Proficiency Test, and filled out a questionnaire related to MIs. Results showed that MIs play a vital role in students' learning behavior and English performance. Hou also concluded that musical, interpersonal, and intrapersonal intelligences has crucial contribution in predicting students' learning behavior, while musical, verbal, and visual intelligences are predictors of English performance.

In the same context, Razmijo \& Jozaghi (2010) carried out a research study to evaluate Top-Notch series through a checklist developed by the researchers based on the elements of the Multiple Intelligences (MI) theory devised by Gardner (1998). The results confirm that Top Notch is rich in addressing verbal intelligence followed by the visual, logical, musical, interpersonal, bodily, and intrapersonal one while to some extent poor in representing natural and existential intelligences.

Naoe (2010) investigated MIs of a group of $5^{\text {th }}$ grade students as a basis for the design and development of curriculum and instructional activities. Participants in the study were $155^{\text {th }}$ grade students, their parents (15), and four teachers who taught the class. A MIs questionnaire, a pretest, and a posttest were administered to examine the MI level of the study sample. Findings indicated the existence of the eight MIs in the learners in varying degrees.

Zarei \& Mohseni (2012) conducted a study to investigate the relationship between four types of intelligence (logical, interpersonal, verbal, and intrapersonal) and grammatical and writing accuracy of foreign language learners. The participants were 190 male and female Iranian students from three public universities. To accomplish the aim of the study, a 40 item MIs questionnaire, a 35 item Michigan grammar test, and a writing test were administered to the participants. Results indicated that both intrapersonal and interpersonal intelligences were predictors of grammar accuracy and intrapersonal intelligence had a statistically significant contribution to predicting learners' writing accuracy.

In a similar context, Nasiri, Ketabi, \& Dastjerdi (2012) examined English Language textbooks which are designed locally for primary education in Iranian public schools to investigate the extent to which they respond to MI theory. The results of this study revealed that the intelligence profile is logical/mathematical and visu$\mathrm{al} /$ spatial. They showed also that Musical and Verbal/Intelligence are identified as the predominant intelligence type, and there was no example of Natural, interpersonal and Intrapersonal intelligences

In Jordan, Al-Shboul and Khawaldeh (2014) carried out a study to examine the level of inclusion and balance of Multiple Intelligences in the Islamic education textbooks of the secondary stage in Jordan. The results of the study showed that the inclusion of the linguistic-verbal and logical-mathematical intelligences are dominating, while all other intelligences (interpersonal, intrapersonal, bodily-kinesthetic, visual-spatial, and naturalistic) are less available. The results also showed that the musical intelligence was not embedded anywhere in the target textbooks.

Arikan, Soydan, \& Isler (2014) carried out a research study to analyze two course books, namely, "Texture of English 4" and "My English 5" on the basis of to what extent the activities and tasks included reflect the intelligent types proposed by multiple intelligences theory. Taking the general characteristics of the intelligences into account, a checklist has been designed and the activities in those two course books were categorized according to the checklist prepared. It is found that although both course books represent different intelligence types and at varying degrees, verbal/linguistic intelligence is the predominant one while the naturalist intelligence is represented the least. Results also showed that there is not any example of existential intelligence.

Finally, Estaji \& Nafisi (2014) conducted a study to investigate the extent to which young students" textbooks reflect and engage multiple intelligences. The results of the study showed that the intelligence profile of these textbooks is mainly verbal/linguistic. They revealed also that Naturalistic intelligence is observed as the least, and no example of spiritual and existential intelligences was found.

Overviewing the previous literature related to MI theory shows that due attention has been paid to multiple intelligences theory as a contemporary perspective in human intelligence and educational settings. However, it is obvious that Arabic Language textbooks in Jordan have not enjoyed the attention of researchers in terms of analyzing the textbooks to investigate the level of MI inclusion in these textbooks. The current study is to add a complementary investigation of multiple intelligences theory in the Arab World where such a line of research has not been in vogue. It is an attempt to examine the utilization of the multiple intelligences in the Arabic lan- 
guage textbooks for their significant role in responding to students' learning styles. It should therefore be taken to enrich the research literature in the domain of multiple intelligences in general and the application of this theory in developing Arabic language textbooks for the first four grades in Jordanian schools and may be in other Arab countries.

\section{Method and Procedures}

\section{1) Study Population and Sample}

The sample of the study is the population itself. It comprises eight Arabic language textbooks for the first four grades in Jordan, covering the first and second semesters 2013/2014. The details of these books as follows:

a) First grade textbooks: It includes two textbooks; one for the first semester containing eight lessons, and another for the second semester containing nine lessons. The activities in the two textbooks comprise a wide range of activities focusing on listen, pronounce and read, write, talk, and chant.

b) Second grade textbooks: It includes two textbooks; one for the first semester containing ten lessons, and another textbook for the second semester containing ten lessons also. The activities in the two textbooks comprise activities focusing on pronounce and read, interpreting words, comprehension and discussion, talking, writing, analysis and composition, listening and answering questions.

c) Third grade textbooks: It includes two textbooks; one for the first semester containing ten lessons, and another one for the second semester containing ten lessons also. The activities in the two textbooks comprise different types of activities focusing on: pronunciation and reading, interpreting words, reading and answering questions, Analysis and composition, talking, writing, and listening and answering questions.

d) Fourth grade textbooks: It includes two textbooks; one for the first semester containing ten lessons, and another one for the second semester containing ten lessons also. The activities in the two textbooks comprise different range of activities focusing on: reading performance, dictionary and semantics, comprehension, linguistic patterns and structures, talking, writing, dictation, listening, drills, and chants.

\section{2) Study Instrument}

To devise the study tool, the researcher reviewed a wide range of literature related to the Multiple Intelligences theory (Gardner, 1983; Gardner, 1999; Armstrong, 1994; Snider, 2001; Estaji \& Nafisi, 2014). The study tool comprises a list representing capabilities and perceptions of each intelligence and a sample of activities from the Arabic language textbooks addressing the following eight intelligences: verbal/linguistic, logical/mathematical, spatial/visual, musical, bodily/kinesthetic, interpersonal, intrapersonal, and naturalist (Appendix A).

To verify the validity of the tool, it was evaluated by ten referees specialized in Educational Psychology and experienced Arabic language teachers for the first four grades in Jordan. The remarks of the referees were taken into consideration, and many indicators were modified accordingly. The reliability of the tool was verified through another specialist of Educational Psychology and teaching of the first four grades who analyzed the eight textbooks. Then, the internal consistency between the two analyses was computed using the Cooper formula. The results showed high level of consistency ranges between (94\% - 97\%).

\section{Procedures of the Study}

a) Two raters identified different kinds of intelligences in each textbook independently: the author of this study and an expert educationist have a great experience in teaching these textbooks and advanced knowledge of MI theory and its intelligences.

b) If the content of any given activity in the textbooks has more than one idea, each idea is considered as a separate one and is consequently allocated for its related type of intelligence.

c) Computing the frequencies of each intelligence indicator and completing a timetable comprising all the intelligences, computing the percentages of each intelligence and applying $\left(\mathrm{X}^{2}\right)$ test for Goodness of Fit.

\section{Results and Discussion}

To answer the questions of the study, the researcher conducted a thorough analysis of the contents of eight Arabic language textbooks for the first four grades in Jordan, in light of the indicators of the MIs theory which were devised by the researcher. The observed frequencies of MIs indicators in Arabic language textbooks were 
recorded, and the percentages of frequency of each MIs indicator were calculated, then conducting the $\left(\mathrm{X}^{2}\right)$ for the goodness of fit test, and calculating the Residual to calculate the Standardized Residual to investigate the status of inclusion, distribution, and balance of MIs indicators in Arabic language textbooks.

Question 1: What is the level of existence and goodness of fit for the Multiple Intelligences in Arabic Language Textbooks of $1^{\text {st }}$ Grade?

To answer question 1, the frequency of each type of the multiple intelligences was computed, and Chi-Square analysis was used. Table 1 reveals the results of question 1 :

Table 1 revealed that the verbal/linguistic intelligence in the textbooks of $1^{\text {st }}$ grade had the most frequency between all of the intelligence types, with percentage of (76.7\%); meanwhile the bodily/kinesthetic intelligence in the textbooks of $1^{\text {st }}$ grade had the least frequency between all of the intelligence types, with percentage of $(0.2 \%)$. The analysis of the textbooks of $1^{\text {st }}$ grade showed that there was no existence of the interpersonal and intrapersonal intelligences in the textbooks. Table 1 revealed that Chi-Square value was (1518.106) with significant level (0.000), which means that there is no balance between the multiple intelligence types in the textbooks of $1^{\text {st }}$ grade.

These results may be attributed to the fact that the designers of $1^{\text {st }}$ grade curriculum and textbooks are not guided by the principles and philosophy of MI theory. It is also obvious that those textbooks of this primary grade stress the importance of verbal/linguistic contents and activities in the first rank then the visual/spatial intelligence, which complies with the developmental characteristics of learners of this age. Non-inclusion of the interpersonal and intrapersonal intelligences in the textbooks of this grade may be attributed to focusing on acquainting students with the basic language skills that could be used later in developing these types of intelligences. The imbalance of the MIs in the respective textbooks may be attributed to not considering the new trend of MIs in authoring these books. The results of this study confirm results of previous studies (Palmberg, 2001; Botelho, 2003; Razmijo \& Jozaghi, 2010), while they differ from other studies (Al-Tawalbeh, 2007; Nasiri, Ketabi, \& Dastjerdi, 2012).

Question 2: What is the level of existence and goodness of fit for the Multiple Intelligences in Arabic Language Textbooks of $2^{\text {nd }}$ Grade?

To answer question 2, the frequency of each type of the multiple intelligences was computed, and Chi-Square analysis was used. Table 2 reveals the results of question 2 :

Table 2 revealed that the verbal/linguistic intelligence in the textbooks of $2^{\text {nd }}$ grade had the most frequency between all of the intelligence types, with percentage of (70.7\%), followed by the intrapersonal intelligence at the rate of $(8.00 \%)$; meanwhile the naturalistic intelligence in the textbooks of $2^{\text {nd }}$ grade had the least frequency among all of the intelligence types, with percentage of (1.1\%). Table 2 also revealed that Chi-Square value was (2536.285) with significant level (0.000), which means that there is no balance between the multiple intelligence types in the textbooks of $2^{\text {nd }}$ grade.

These results may be attributed to the nature of knowledge and experiences provided at this more advanced level and to the level of basic language skills acquainted by students who become more able to use language and reflect on themselves. Once again the very low rates of frequency for the musical and naturalistic intelligences could be explained through not complying with the guidelines of MI theory. The results of this study confirm results of previous studies (Palmberg, 2001; Botelho, 2003), while they differ from other studies (Nasiri, Ketabi, \& Dastjerdi, 2012; Al-Shboul \& Khawaldeh 2013).

Table 1. Chi-square analysis results to compute the level of multiple intelligences in Arabic language textbooks of $1^{\text {st }}$ grade.

\begin{tabular}{|c|c|c|c|c|c|c|c|}
\hline Intelligence type & Observed & Percent (\%) & Expected & Residual & Chi-Square & df & Sig. \\
\hline Verbal/linguistic & 427 & 76.7 & 92.8 & 334.2 & \multirow{6}{*}{1518.106} & \multirow{6}{*}{5} & \multirow{6}{*}{0.000} \\
\hline Logical/mathematical & 14 & 2.5 & 92.8 & -78.8 & & & \\
\hline Bodily/kinesthetic & 1 & 0.2 & 92.8 & -91.8 & & & \\
\hline Musical & 8 & 1.4 & 92.8 & -84.8 & & & \\
\hline Visual/spatial & 100 & 17.9 & 92.8 & 7.2 & & & \\
\hline Naturalistic & 7 & 1.3 & 92.8 & -85.8 & & & \\
\hline Total & 557 & 100 & - & - & - & - & - \\
\hline
\end{tabular}


Table 2. Chi-square analysis results to compute the level of multiple intelligences in Arabic language textbooks of $2^{\text {nd }}$ grade.

\begin{tabular}{|c|c|c|c|c|c|c|c|}
\hline Intelligence type & Observed & Percent (\%) & Expected & Residual & Chi-Square & df & Sig. \\
\hline Verbal/linguistic & 573 & 70.7 & 101.4 & 471.6 & \multirow{8}{*}{2536.285} & \multirow{8}{*}{7} & \multirow{8}{*}{0.000} \\
\hline Logical/mathematical & 27 & 3.3 & 101.4 & -74.4 & & & \\
\hline Interpersonal & 35 & 4.3 & 101.4 & -66.4 & & & \\
\hline Intrapersonal & 65 & 8.0 & 101.4 & -36.4 & & & \\
\hline Bodily/kinesthetic & 30 & 3.7 & 101.4 & -71.4 & & & \\
\hline Musical & 11 & 1.4 & 101.4 & -90.4 & & & \\
\hline Visual/spatial & 61 & 7.5 & 101.4 & -40.4 & & & \\
\hline Naturalistic & 9 & 1.1 & 101.4 & -92.4 & & & \\
\hline Total & 811 & 100 & - & - & - & - & - \\
\hline
\end{tabular}

Question 3: What is the level of existence and balance of the Multiple Intelligences in Arabic Language Textbooks of $3^{\text {rd }}$ Grade?

To answer question 3, the frequency of each type of the multiple intelligences was computed, and Chi-Square analysis was used. Table 3 reveals the results of question 3 :

Table 3 revealed that the verbal/linguistic intelligence in the textbooks of $3^{\text {rd }}$ grade had the most frequency between all of the intelligence types, with percentage of (64.5\%), followed by interpersonal intelligence at the rate of $(7.7 \%)$; meanwhile the musical intelligence in the textbooks of $3^{\text {rd }}$ grade had the least frequency between all of the intelligence types, with percentage of (1.7\%). Table 3 also revealed that Chi-Square value was (2504.564) with significant level (0.000), which means that there is no balance between the multiple intelligence types in the textbooks of $3^{\text {rd }}$ grade.

These results could be attributed to the nature of language textbooks which focus mainly on the verbal and linguistic components, while the increase of interpersonal intelligence may be attributed to the development of students' developmental social characteristics and acquisition of more advanced language tools that could enhance their communication skills with others. The musical intelligence ranked least in this grade, may be because music is not highly appreciated as a learning tool in Arab societies in general, and because no specialists in music participate in authoring Arabic language textbooks for this grade and other grades as well. The imbalance among intelligences embedded in these textbooks could be attributed to non-compliance with the principles and thoughts of MI theory. These results confirm results of previous studies (Palmberg, 2001; Botelho, 2003), while they differ from other studies (Nasiri, Ketabi, \& Dastjerdi, 2012; Al-Tawalbeh, 2007).

Question 4: What is the level of existence and goodness of fit for the Multiple Intelligences in Arabic Language Textbooks of $4^{\text {th }}$ Grade?

To answer question 4, the frequency of each type of the multiple intelligences was computed, and Chi-Square analysis was used. Table 4 reveals the results of question 4 :

Table 4 revealed that the verbal/linguistic intelligence in the textbooks of $4^{\text {th }}$ grade had the most frequency between all of the intelligence types, with percentage of (70.4\%), followed by intrapersonal intelligence at the rate of (9.5\%); meanwhile the Bodily/kinesthetic intelligence in the textbooks of $4^{\text {th }}$ grade had the least frequency between all of the intelligence types, with percentage of $(0.6 \%)$. Table 4 also revealed that Chi-Square value was (3101.559) with significant level (0.000), which means that there is no goodness of fit between the multiple intelligence types in the textbooks of $4^{\text {th }}$ grade.

These results may be explained through considering students' development in all aspects and focusing more on intrapersonal skills in addition of course to verbal/linguistic intelligence which dominates all other intelligences. In accordance with different developmental aspects related to this grade level, the authors not relying on MI theory gave more attention to intrapersonal, interpersonal and logical-mathematical intelligences. However, musical intelligence remains the least frequent as in other grade levels due to cultural considerations. These results confirm results of previous studies (Palmberg, 2001; Botelho, 2003), while they differ from other studies (Nasiri, Ketabi, \& Dastjerdi, 2012; Al-Shboul \& Khawaldeh, 2013). 
Question 5: What is the level of existence and balance of the Multiple Intelligences in Arabic Language Textbooks as a whole?

To answer question 5, the frequency of each type of the multiple intelligences was computed, and Chi-Square analysis was used. Table 5 reveals the results of question 5 :

Table 3. Chi-square analysis results to compute the level of multiple intelligences in Arabic language textbooks of $3^{\text {rd }}$ grade.

\begin{tabular}{ccccccc}
\hline Intelligence type & Observed & Percent (\%) & Expected & Residual & Chi-Square & df \\
\hline Verbal/linguistic & 648 & 64.5 & 125.6 & 522.4 & & \\
Logical/mathematical & 61 & 6.1 & 125.6 & -64.6 & & \\
Interpersonal & 59 & 5.8 & 125.6 & -66.6 & & \\
Intrapersonal & 78 & 7.7 & 125.6 & -47.6 & 2504.564 & 7 \\
Bodily/kinesthetic & 28 & 2.8 & 125.6 & -97.6 & & \\
Musical & 17 & 1.7 & 125.6 & -108.6 & & -600 \\
Visual/spatial & 65 & 6.5 & 125.6 & -60.6 & & - \\
Naturalistic & 49 & 4.9 & 125.6 & -76.6 & & - \\
Total & 1005 & 100 & - & & -
\end{tabular}

Table 4. Chi-square analysis results to compute the level of multiple intelligences in Arabic language textbooks of $4^{\text {th }}$ grade.

\begin{tabular}{|c|c|c|c|c|c|c|c|}
\hline Intelligence type & Observed & Percent (\%) & Expected & Residual & Chi-Square & $\mathrm{df}$ & Sig. \\
\hline Verbal/linguistic & 702 & 70.4 & 124.8 & 577.3 & \multirow{8}{*}{3101.559} & \multirow{8}{*}{7} & \multirow{8}{*}{0.000} \\
\hline Logical/mathematical & 55 & 5.5 & 124.8 & -69.8 & & & \\
\hline Interpersonal & 69 & 6.9 & 124.8 & -55.8 & & & \\
\hline Intrapersonal & 95 & 9.5 & 124.8 & -29.8 & & & \\
\hline Bodily/kinesthetic & 6 & 0.6 & 124.8 & -118.8 & & & \\
\hline Musical & 18 & 1.8 & 124.8 & -106.8 & & & \\
\hline Visual/spatial & 31 & 3.1 & 124.8 & -93.8 & & & \\
\hline Naturalistic & 22 & 2.2 & 124.8 & -102.8 & & & \\
\hline Total & 998 & 100 & - & - & - & - & - \\
\hline
\end{tabular}

Table 5. Chi-square analysis results to compute the level of multiple intelligences in Arabic language textbooks in general.

\begin{tabular}{|c|c|c|c|c|c|c|c|}
\hline Intelligence type & Observed & Percent (\%) & Expected & Residual & Chi-Square & df & Sig. \\
\hline Verbal/linguistic & 2350 & 69.7 & 421.4 & 1928.6 & \multirow{8}{*}{10182.535} & \multirow{8}{*}{7} & \multirow{8}{*}{0.000} \\
\hline Logical/mathematical & 157 & 4.7 & 421.4 & -264.4 & & & \\
\hline Interpersonal & 163 & 4.8 & 421.4 & -258.4 & & & \\
\hline Intrapersonal & 238 & 7.1 & 421.4 & -183.4 & & & \\
\hline Bodily/kinesthetic & 65 & 1.9 & 421.4 & -356.4 & & & \\
\hline Musical & 54 & 1.6 & 421.4 & -367.4 & & & \\
\hline Visual/spatial & 257 & 7.6 & 421.4 & -164.4 & & & \\
\hline Naturalistic & 87 & 2.6 & 421.4 & -334.4 & & & \\
\hline Total & 3371 & 100 & - & - & - & - & - \\
\hline
\end{tabular}


Table 5 revealed that the verbal/linguistic intelligence in the textbooks in general had the most frequency between all of the intelligence types, with percentage of (69.7\%), followed by visual-spatial intelligence with a rate of (7.6\%); meanwhile the musical intelligence in the textbooks had the least frequency between all of the intelligence types, with percentage of (1.6\%). Table 5 also revealed that Chi-Square value was (10182.535) with significant level (0.000), which means that there is imbalance between the multiple intelligence types in the textbooks as a whole.

These results may be attributed to the nature of language textbooks in general which focus on vocabulary, semantics, linguistic structures, reading \& writing, listening, and speaking. They could be interpreted also in light of the lack of proper experience and knowledge of MI theory which needs further efforts from all concerned parties in Jordan to be adopted as a new trend in designing and authoring curricula and textbooks in language and other schools subjects as well. Musical intelligence remains the least frequent among all intelligences, which might be attributed to misunderstanding the role of music in enhancing learning and providing more positive and conducive learning environments. The imbalance among the eight intelligences in the textbooks of the first grades may be attributed to absenteeism of the vision as stipulated by the MI theory, and due to the lack of guidelines addressing building school textbooks in Arabic language or any other textbooks from the perspective of Multiple Intelligences theory.

\section{Conclusion and Recommendations}

To conclude, literature on multiple intelligences as proposed by Howard Gardner shows the significance of a multidimensional approach of education and highlights a number of neglected key considerations in the area of teaching and learning. Intelligence and its implications have influenced education and its different methodologies. The differences between our present century and previous centuries are clearly observed in the ways our views have altered as a result of diversity, technology, and new trends of globalization. Education in general and its school textbooks in particular must encompass a variety of methods in order to respond to student's multiple learning styles. A globally recognized way to address this is to comprehend and consider the potential of multiple intelligences to change the ways of our thinking, learning and teaching processes. However, in spite of the global recognition of the crucial importance of including MIs in the textbooks to meet the different individual learning styles, this study reveals that verbal/linguistic dominates the Arabic language textbooks for the first four grades in Jordan, while other intelligences have enjoyed minimal consideration, which indicates frankly that relevant textbooks need drastic changes to accommodate students' needs and respond deliberately to their different learning styles. In the light of the previous results the study proposes the following recommendations:

1) Adopting the MIs theory in designing Arabic language textbooks for the first four grades in Jordan.

2) Maintaining a balance of including all MIs in the Arabic Language textbooks to ensure better learning opportunities for students of the lower basic education stage in Jordan.

3) Conducting further studies on Arabic language textbooks to investigate the level and balance of MIs for grades from (5 - 12) in Jordan.

\section{References}

Al-Shboul, A., \& Al-Khawaldeh, N. (2014). Analysis of Islamic Education Textbooks in Jordan in Light of Intelligences Theory. The Jordanian Journal of Educational Sciences, 10, 293-304.

Al-Tawalbeh, H. M. (2007). Analysis of the Tenth Grade History Textbook on the Basis of Multiple Intelligences and Measuring the Effect of a Developed Unit on Students' Intelligences and Achievement. Unpublished Dissertation, Irbid: Yarmouk University.

Arikan, A., Soydan, E., \& Isler, O. (2014). A Study of Two English Language Course Books in Turkey: Focus on Multiple Intelligences. Journal of Education, 1, 27-33.

Armstrong, T. (1994) Multiple Intelligences: Seven Ways to Approach Curriculum. Educational Leadership, 52, $26-28$.

Armstrong, T. (2009). Multiple Intelligences in the Classroom (3rd ed.). Alexandria, VA: Association for Supervision \& Curriculum Development.

Arnold, J., \& Fonseca, C. M. (2004). Multiple Intelligence Theory and Foreign Language Learning: A Brain-Based Perspective. International Journal of English Studies, 4, 119-136.

Botelho, M. R. (2003). Multiple Intelligences Theory in English Teaching: An Analysis of current Textbooks, Materials and Teachers' Perceptions. Unpublished Thesis, Athens, OH: Ohio University.

Campbell, I. M. (2000). The Unspoken Dialogue: Beliefs about Intelligence, Students, and Instruction Held by a Sample of 
Teachers Familiar with the Theory of Multiple Intelligences. Unpublished Ph.D. Dissertation, Santa Barbara, CA: The Fielding Institute.

Ehrman, M. E., (2003). A Brief Overview of Individual Differences in Second Language Learning. System, 31, $313-330$. http://dx.doi.org/10.1016/S0346-251X(03)00045-9

Estaji, M., \& Nafisi, M. (2014). Multiple Intelligences and Their Representation in the EFL Young Learners' Textbooks. International Journal of Research Studies in Language Learning, 3, 61-72. http://dx.doi.org/10.5861/ijrsll.2014.731

Gardner, H. (1983). Frames of Mind. New York: Basic Books.

Gardner, H. (1999). Intelligence Reframed: Multiple Intelligences for the 21st Century. New York: Basic Books.

Goodenough, K. (2000). Exploring Multiple Intelligences Theory in the Context of Science Education: An Action Research Approach. UMI Dissertations. http://wwwlib.umi.com/dissertations/preview_all/NQ4985

Griggs, L., Barney, S., Brown-Sederberg, J., Collins, E., Keith, S., \& Iannacci, L. (2009). Varying Pedagogy to Address Student Multiple Intelligences. Human Architecture, 7, 55-60. http://search.proquest.com/docview/210172456?accountid=14129

Hoerr, T. (2000). Becoming a Multiple Intelligences School. Alexandria, VA: Association for Supervision and Curriculum Development (ASCD).

Hou, Y.-A. (2010). Multiple Intelligences and Foreign Language Learning: A Case Study in Taiwan. The International Journal of the Humanities, 8, 77-106.

Hyland, A. (2011). Multiple Intelligences: Curriculum and Assessment Project (Final Report 2000). Education Department, University College Cork, Digitized Version. The National Academy for Integration of Research, Teaching and Learning.

Johnson, M. (2007). An Extended Literature Review: The Effect of Multiple Intelligences on Elementary Student Performance. Unpublished Thesis, San Rafael, CA: Dominican University of California.

Kelly, D. (2005). On the Dynamic Multiple Intelligence Informed Personalization of the Learning Environment. Unpublished Ph.D. Dissertation, Dublin: University of Dublin, Trinity College.

McFarlane, D. A. (2011). Multiple Intelligences: The Most Effective Platform for Global 21st Century Educational and Instructional Methodologies. College Quarterly, 14, 1-8.

Naoe, G. D. (2010). The Multiple Intelligences of Grade V Pupils: Bases for the Proposed Learning Enhancement Program of David Elementary School. E-International Scientific Research Journal, 2, 90-109.

Nasiri, M., Ketabi, S., \& Dastjerdi, H. (2012). Multiple Intelligences in Locally-Published ELT Textbooks in Iran. Modern Journal of Applied Linguistics, 4, 258-266.

Okebukola, F., \& Owolabi, T. (2009). Improving the Reading Ability of Science Students through Study Groups and Multiple Intelligences. US-China Education Review, 6, 38-43.

Palmberg, R. (2001). Catering for Multiple Intelligences in EFL coursebooks. HLT Magazine, January 2002. http://www.htlmag.co.uk/Jan02/sart6htm

Razmijo, S. A., \& Jozaghi, Z. (2010). Multiple Intelligences, Student-Centered Learning: Textbooks Evaluation. Journal of Pan-Pacific Association of Applied Linguistics, 14, 59-84.

Richards, J. C. (2001). The Role of Textbooks in a Language Program. Cambridge, UK: Cambridge University Press. http://www.cup.org.br/articles/articles 21.html

Sheldon, L. E. (1988). Evaluating ELT Textbooks and Materials. ELT Journal, 42, 237-246. http://dx.doi.org/10.1093/elt/42.4.237

Silver, H., Strong, R., \& Perini, M. (1997). Integrating Learning Styles and Multiple Intelligences. Educational Leadership, $55,22-27$.

Snider, D. P. (2001). Multiple Intelligences Theory and Foreign Language Teaching. Unpublished Ph.D. dissertation, Salt Lake City, UT: University of Utah.

Stefanakis, E. H. (2002). Multiple Intelligences and Portfolios: A Window into the Learner's Mind. Portsmouth: Heinemann.

Tahriri, A., \& Divsar, H. (2011). EFL Learner’s Self-Perceived Strategy Use across Various Intelligence Types: A Case Study. Journal of Pan-Pacific Association of Applied Linguistics, 15, 115-138.

Weiner, A. G. (2001). Investigating Commonalities among Elementary Schools That Have Implemented the Theory of Multiple Intelligences: A Guideline for the 21st Century. Unpublished Ph.D. Dissertation, Bethlehem, PA: Lehigh University.

White, N., Blythe, T., \& Gardner, H. (1995) Multiple Intelligences Theory: Creating the Thoughtful Classroom. In R. Fogarty, J. Bellanca, \& M. Hauker (Eds), Multiple Intelligences: A Collection. Melbourne: Hawker Brownlow Education.

Zarei, A., \& Mohseni, F. (2012). On the Relationship between Multiple Intelligences and Grammatical and Writing Accuracy of Iranian Learners of English. US-China Foreign Language, 10, 1306-1317. 


\section{Appendix (A)}

Sample activities addressing various intelligences as represented in the Arabic language textbooks for grades from $(1-4)$ in Jordan

\begin{tabular}{|c|c|c|}
\hline Intelligence type & Capability and perceptions & Sample activities from the Arabic language textbooks \\
\hline Verbal/linguistic & $\begin{array}{l}\text { Words and language, speak, } \\
\text { read, write, talk, discuss, } \\
\text { analyze, compose, describe }\end{array}$ & $\begin{array}{l}\text { Name the pictures below } \\
\text { Answer the following questions } \\
\text { Read the following sentence } \\
\text { Choose the correct answer } \\
\text { Compose a meaningful sentence } \\
\text { Analyze the following words } \\
\text { Match the word with its meaning } \\
\text { Compose a word from the below letters } \\
\text { Describe what you see in the picture } \\
\text { Complete the following sentences } \\
\text { Write a short paragraph about pollution }\end{array}$ \\
\hline Logical/mathematical & $\begin{array}{l}\text { Logic, numbers, reasoning, } \\
\text { perdition, cause and effect, } \\
\text { understanding from texts }\end{array}$ & $\begin{array}{l}\text { Color letters to form a pattern } \\
\text { Suggest a suitable title to the lesson } \\
\text { Write a sentence about the expected consequences } \\
\text { Complete a sentence using a given example } \\
\text { Give reasonable solutions } \\
\text { Match between causes with results } \\
\text { Follow the arrows to form meaningful words } \\
\text { Explain abundance of agriculture in Jordan valley } \\
\text { Give proofs from given texts } \\
\text { Complete words starting with certain letters }\end{array}$ \\
\hline Spatial/visual & $\begin{array}{l}\text { Link pictures with concepts, } \\
\text { illustrations, tables, figures, } \\
\text { imaginations, pictures, maps, } \\
\text { charts, colors, diagrams, } \\
\text { arts and drawings }\end{array}$ & $\begin{array}{l}\text { Draw pictures and figures } \\
\text { Discuss the features of a picture or a figure } \\
\text { Color the picture with most suitable colors } \\
\text { Use a picture to complete a story } \\
\text { Arrange figures to write a meaningful sentence } \\
\text { Imagine a figure, draw it and color it } \\
\text { Explain the inference of each of the following pictures } \\
\text { If you were the mother, what you suggest? } \\
\text { Describe what you see in the picture } \\
\text { Collect pictures about ... and explain it to students }\end{array}$ \\
\hline Musical & $\begin{array}{l}\text { Music, sound, rhythm, } \\
\text { songs, chants, } \\
\text { playing music }\end{array}$ & $\begin{array}{l}\text { Let's sing together } \\
\text { Listen to the words and sing } \\
\text { Chant together group by group }\end{array}$ \\
\hline Bodily/kinesthetic & $\begin{array}{l}\text { Hands-on activities, field trips, } \\
\text { role play, body language, } \\
\text { movement control, }\end{array}$ & $\begin{array}{l}\text { Role playing a story } \\
\text { Draw pictures using the computer painter } \\
\text { Perform activities using the computer software } \\
\text { Collect pictures for different professions } \\
\text { Design a poster to explain the risks of } \\
\text { Visit some tourism sites in Jordan } \\
\text { Use body movements to express emotions and feelings } \\
\text { Type words and sentences using texts processor } \\
\text { Prepare with the teacher an Arabic Language magazine } \\
\text { Record chants and listen to them with classmates }\end{array}$ \\
\hline Interpersonal & $\begin{array}{l}\text { Pair work, cooperative work, } \\
\text { group brainstorming, } \\
\text { group games, discussions, } \\
\text { peer review, social language, } \\
\text { project work }\end{array}$ & $\begin{array}{l}\text { Collect with your classmates poems about Jordan river } \\
\text { Prepare in pairs questions for cultural competitions } \\
\text { Discuss with your group the traffic rules in your town } \\
\text { Prepare in groups the disadvantages of telephones } \\
\text { Discuss the role of computers in manufacturing } \\
\text { Cooperate in a project to elevate poverty in your town } \\
\text { Exchanging ideas and feelings about raising up pets } \\
\text { Participate in collecting information about Petra } \\
\text { Collect with students pictures about tourism in Jordan } \\
\text { Classify -in pairs - the animals based on their food }\end{array}$ \\
\hline
\end{tabular}




\section{Continued}

\begin{tabular}{|c|c|c|}
\hline Intrapersonal & $\begin{array}{l}\text { Self-evaluation, interests, } \\
\text { opinions, moods, } \\
\text { desires and intentions, } \\
\text { personal journals, } \\
\text { individual plans and projects, } \\
\text { personal likes and dislikes, } \\
\text { self-awareness, self-discovery }\end{array}$ & $\begin{array}{l}\text { Draw a lion and choose the color you like } \\
\text { Read a story and suggest the end from your view point } \\
\text { Suggest ideas to protect your school from pollution } \\
\text { Choose a poem and explain why do you like it } \\
\text { What do you think about the farmer who quit farming } \\
\text { Talk about what you disliked in a wedding you attended } \\
\text { Write about the TV programs you prefer to watch } \\
\text { Choose a sentence you liked from the reading lesson } \\
\text { How do you behave if you were in Ahmad's place? } \\
\text { How do you think the turtle win a race with the rabbit? }\end{array}$ \\
\hline Naturalist & $\begin{array}{l}\text { Natural environment, } \\
\text { listing characterizes of, } \\
\text { categorizing nature items, } \\
\text { recognize and classify plants, } \\
\text { minerals and animals } \\
\text { including rocks and glass }\end{array}$ & $\begin{array}{l}\text { Listen then talk about Spring season } \\
\text { Imagine a rabbit and draw it on the board } \\
\text { Draw a picture represents olive cultivation season } \\
\text { Name medical herbals and write them in your book } \\
\text { Write the characteristics of fish } \\
\text { What is your favorite flower? Why? } \\
\text { What is your favorite season and why? } \\
\text { Name the birds mentioned in the listening text } \\
\text { Visit a farm and classify its trees based on given criteria } \\
\text { What are the impacts of pollution in your area }\end{array}$ \\
\hline
\end{tabular}

